\title{
The Petrified Utopia: Monumental Propaganda, Architecture Parlante, and the Question about (De)Materialisation of Monuments
}

\author{
Katarzyna Trzeciak \\ Jagiellonian University
}

\begin{abstract}
The article examines the idea of monumentality (following Evgeny Dobrenko's concept of "petrified utopia") in Polish Socialist literature especially by analyzing Lenin's "monumental propaganda" and its influence on literary thinking. Starting from some details about Lenin's vision and plan, the article will further present how the act of transposition of a monument into texts - the act of materialization monuments in literary signs — causes some kind of monumental spectrality or dematerialization and as a consequence, the disappearance of art in Rancieran sense in which the art disappears when it becomes transparent for itself. To prove this thesis, the article will analyze two main architectural examples: Tatlin's Monument to the Third International (as the great realization of Lenin's doctrine) and Polish Palace of Culture and Science which was the theme of many Polish Socialist poems. In conclusion, the article will also present some broader perspective of modern architectural utopias and their spectrality.
\end{abstract}

Keywords: monumental propaganda, sculpture, Monument to the Third International, spectrality, Architecture Parlante

"Buildings were to 'say much, both powerfully and convincingly.' They were to be read as texts" (Cark $2009,224)$. The term "monumental propaganda" refers to such reading the buildings as a literary text. It also shows the connection between utopian aspects of political and aesthetic project of socialist realism presented in sculptural and architectural discourse in relations to some literary concepts. In my article, I would like to begin with some details about Lenin's vision of monumental propaganda, then I'd try to show how the act of transposition of a monument into texts - the act of materialization monuments in literary signs - causes some kind of monumental spectrality or dematerialization and as a consequence, the disappearance of art in Rancieran sense in which the art disappears when it becomes transparent for itself (Ranciere 2004, 110).

Monuments operate as visual symbols of power which aspire to control both time and space by demonstratively monopolizing the construction of historical narratives. As James Rann claims, "The primary function of the monument is ostensibly to commemorate the dead. Monuments therefore serve as a sort of life after death and a riposte to the onward march of time: The statue's solidity and immobility communicate a

Katarzyna Trzeciak, Ph.D. candidate, Faculty of Polish Studies, Jagiellonian University, Poland; main research field: Literary Anthropology and Literary Theory. Email: k_trzeciak@o2.pl.

The research was financed by Narodowe Centrum Nauki (National Centre of Science), the number of decision DEC-2012/05/N/HS2/02707. 
rejection of the effects of time and death" (Rann 2012,769).

Mikhail Yampolsky calls monuments "islets of eternity in the movement of time" (Rann 2012, 769). Monuments are therefore an invocation of eternity which is used to establish past and future continuity of the regime.

Lenin's plan for monumental propaganda, enunciated and implemented in April 1918, has to deal with this monument's life after death property in order to establish a specifically political relationship between Soviet art and Soviet government. The first step is the removal of old Tsarists monuments as a symbol of archaic and yet lifeless power. The poet Vladimir Maiakovski, strongly opposes such iconoclastic approach and proposes instead a strategy beyond the binary iconoclastic tradition: instead of destroying the statue as an embodiment of the past he dreams of mobilizing it, letting it wander free to find a place in modern society (as in his "Posledniaia peterburgskaia skazka"- The Last Petersburg Fairy Tale — in which we can read about Pushkin's Bronze Horseman leaving his pedestal to have a dinner in Astoria Hotel restaurant). Lenin's plan, in Maiakovski's view, is not moving fast enough and the poet used the metaphor of Tsarists statues standing still on Uprisings Square (Rann 2012, 772). Such vision of immobile statue is a symbol of the lingering presence of the old culture in general confronted with the dynamism of the revolution.

Nevertheless, Lenin sees his plan as a continuation of Campanella's City of the Sun. However, in contrast to Campanella's vision in which walls of the city should be covered with frescoes serving the youth as a graphic lesson in natural science and history, Lenin's replaced frescoes with statues containing plaques with slogans and citations. This combination suggests that Plan for Monumental Propaganda advocates and embodies the idea of a synthesis of arts. Sculpture, architecture, and literature should therefore be harnessed to the service of the state and its ideology.

\section{Writing of the Surface}

In the term of monumental propaganda, the word "propaganda" refers to "verbocentrism" which means that all monuments (architecture and sculpture) need the verbal, textual support which functions as a translation for all ideological senses of monumentality. For this reason, Polish scholar, Wojciech Tomasik, in his book Engineering of the Souls, points that for Stalinist culture the crucial traditions standing behind both architecture and literature are the directives of Architecture Parlante derived from French Revolution (Tomasik 1999, 7). French architecture in the late 18th century was supposed to be a reflection of speech and energy of classes that had come to power by revolution. And it had to use less formal and less sophisticated language understandable and persuasive for everyone. Léon Dufourny, an architect, says even that walls should speak, like a poem, and sentences should transform buildings into objects of moral strength (Lipka 1994, 135). According to Enlightenment theorists, Architecture Parlante is an art of creating buildings like monuments enlightening by symbols and texts about citizens' duties and rights. An architect is a philosopher and a moralist or a guide with special mission.

Architectural message required narrative details as shows may be one of the best examples of Architecture Parlante - the project of "Temple to Equality" by Alexis-François Bonnet from 1794 in Paris Sacred Mountain. An important element of the project is the description in which the author presents the ideas communicated by the building. He explains each symbol of the temple, for example the statue of Hercules symbolizing the victorious people or other metaphors of Reason and Tyranny. The architectural language of metaphors thus attains the highest significance. But for adequate perception, all the metaphors should be 
explained by the narration. Without it, they would stay illegible.

In Lenin's plan, the new symbols that spring up around the revolution are almost identical in motif to those of 1789: Broken chains evoke liberation, the harmony of exploited classes, and the hydra of counterrevolution. Rituals, monuments, and festive commemorations emblems provide a new set of symbols to replace those of the past. At the same time, in monumental propaganda based on the tradition of Architecture Parlante and simultaneously anticipating the Soviet style, all great buildings and sculpture mean only in cooperation with textual, discursive support. Katerina Clark argues that:

Architecture cannot, per se, narrate a biography, or at any rate, can do so to only a very restricted degree. The regime needed not just "beautiful" buildings, mere shells, nor even model cities as structures of streets and amenities. It also needed a narrative about that shell to give it order, cogency and, above all, meaning. Thus, although the branches of the arts (especially literature and architecture) were all linked in the thirties, literature was dominant because it relates part to whole not just in an abstract way, as in architecture, but in a human narrative. (Clark 2009, 225)

But there is something else in this discursive character of revolutionary architecture. It's superficiality. Architecture Parlante derives its justification from the 19th century physiognomic theories. Thanks to this background, there is a specific similarity between the buildings and a human body. Order, symmetry, and harmony have been present only in the external appearance, represented by the facade. Inside, similar to the human body inside, the beauty disappears giving way for utility; symmetry and aesthetic unity are annihilated. Facade promises an internal order, but looking inside, we find chaos and decomposition. Facade thus acts as a mask which at the same time articulates architectural harmony. But it is just the writing of the surface (Cembrzynska 2012, 318).

\section{Endless Text}

Boris Groys in his study about total art of Stalinism puts some important explanations of this process in context of socialist realism productions. He mentions that in Stalinist artworks are no stable reference to the real world - they do not correspond to anything anywhere in reality. They are pure wholly self-sufficient utterances. Groys quotes Ilia Kabakov's statements about this textuality:

Text, which everyone knows is addressed to no one, signifies nothing, corresponds to nothing, nevertheless means a great deal in itself, so that interest, attention, work with this text is what constitutes the peculiarity of our production. This is all the more important in view of the fact that the text permeates our entire life... but it would be inadvisable to think that these texts are directed to a human subject or address the "Soviet individual." Our art is even more unique than it appears at first glance. Our texts address only texts, and every text is a text responding to some preceding text. (Groys 1992, 87)

The everyday and ideology have coincided in the endless text. Good example of such autoreferential strategy in monumental propaganda is Tatlin's Monument to the Third International (1919-1920) which has actually never arisen. This monument represents kind of "paper architecture" or "architecture of wishful thinking" appropriate to the history of many modern utopias. Tatlin combines architecture with sculpture to mock with the pathos of official standards of architecture and simultaneously to propose the new formula for its realization. Its basic exoskeleton is an open double spiral, rising along an axis that is parallel to the axis of the earth. "The spiral (declared Tatlin) is the most effective symbol of the modem spirit of the age: the spiral which, rising from the earth, detaches itself from all animal, earthly, and oppressing interests and forms the purest expression of humanity set free by the revolution" (Klosty Beaujour 1988, 54). The dynamism inherent in the spiral itself is accentuated by the fact that the four suspended glass interior volumes are designed to rotate at 
different speeds. Although their motion would have been too slow to be visible to the naked eye, the general view of the basic parts of the construction would be constantly changing due to the different relations of the moving volumes to the immovable parts. Therefore, Tatlin's monument is a moving monument designed to stimulate movement in its users. Ilia Erenburg is dazzled as he contemplates the Tatlin's tower. Indeed, it is the monument for contemplation and as such, according to Debord, that which could provoke "imprisonment in a dream" (Cembrzynska 2012, 99). Debord points that the more we contemplate, the less we live, because object of contemplation creates kind of spectator's alienation in the contemplative object. There is no real referent for the Tatlin's monument, and it signifies nothing and corresponds to nothing like the Eiffel Tower describing by Roland Barthes. The Paris Tower is pure virtually empty sign which means everything. In order to negate it, it should stand on it and identify ourselves with it.

The Tower attracts meaning, the way a lightning rod attracts thunderbolts; for all lovers of signification, it plays a glamorous part, that of a pure signifier, i.e., of a form in which men unceasingly put meaning (which they extract at will from their knowledge, their dreams, their history), without this meaning thereby ever being finite and fixed. (Barthes 1989, 2)

The Eiffel Tower is pure externality in which nothing can be hidden. In Tatlin's monument, the great realization of monumental propaganda, such externality is kind of mockery of all the doctrinal rules exposing the necessity of communication. Monument to the Third International maximizes the assumption about discursive aspect of architecture. It is only discursive in having just its externality. Monumental utopia, designed to provoke ideological awakening, in fact is attracting by its spectrality or even irrationality. Tatlin creates the world of tomorrow, the world of pure beauty and offers to Tower's viewers a kind of confrontation with their own dreams. It is an extreme consequence of moral mission which Socialist architects project into buildings. They need some mystical communication between the viewers and all those ideas, truths, and doctrine embodied in the architecture.

\section{Toward the Future}

Tatlin's Tower thus represents what Boris Groys sees as a socialist realism property of orientation toward which has not yet come into being but which should be created (Groys 1992, 51). But at the same time (what made Anatolij Lunacharskii so suspicious), it transgresses all the crucial rules of Lenin's plan revealing its irrational foundations. Monument is some kind of utopian scandal in the middle of utopian thinking.

In Socialist culture, which I call as "verbocentric," literature is intended as a support for architectural transmission of ideological ideas. In Polish tradition, 1949 is the turning point of postwar art especially due to reanimation of Architecture Parlante. Architectural form is intertwined with writing activity like writers act in cooperation with architects. In Polish Socrealist poems, this relationship is represented for example by the identity of "bricklaying" and "writing." This is the case of Jerzy Ficowski: "Today we need put the foundations like a bricklayer, when building a house," or Arnold Słucki: "Each rhyme to build a new lets the poems like buildings are piling." Such metaphors activate the view of world as a text whose essence should be unveiled and interpreted properly. In those poems, the subject is a hermeneutist who explains all the meanings of the new ionosphere. He acts like a medium between the statement encrypted in architecture and the people who need verbal translation of those ideas. But this essence again refers, as Derridean écriture, to another trace-metaphors and texts play endlessly with different topic which need another explanation and another. Each poem tells the same story of dreams thanks to which the people can look into the future with hope and happiness. 
In 1946, Bolesław Bierut, chairman of State National Council, proclaimed the program of rebuilding Warsaw, and he drew attention that the capital city of Poland should have the new, beautiful view, worthy the epoch of the new humanism. Together with the coming of the epoch, Warsaw needed new architecture. Henceforth, everything had to be greater, bigger and the material symbol of those dreams was supposed to be the Palace of Culture and Science. From the very beginning, the Palace was mythologized as everybody knew that the "gift from the Soviet people to the Polish nation" had to be enormous and became the beginning of a revolutionary reconstruction.

\section{Spectrality of Solid Masses}

Viewed from the outside, the Palace has to give the impression of flowing upwardly, dissolving the solid in the sky. Starting from monumental, stubby down, throughout the slender figure of main corpus, until the spire crowning the object, there is a suggestion of dematerializing of the monument. Many reports or other testimonies of the viewers repeat endlessly the effect of uniqueness and weirdness which emanats from the Palace. The monument, as one of the viewers noticed, has been present before it actually erects (Benedyktowicz 1991, 23). Many poems create the Palace as an oxymoron-besides the image of power, stability, and durability, we can see the monument as something which is constantly in dynamic progress connected with flying and ascension. Similar to Tatlin's monument, the Warsaw Palace expresses the desire for mobility freed from the weight of the solid masses. The literary texts about this great monument treated as a metaphor of the new life or a new humanism, as Bierut wants. But it is a practice that demands the total dematerialization of the monument, deprivation it of empirical solidity. Derrida describes similar process in philosophy which needs the metaphor of architecture to explain the reality as a building activity. Philosophy uses this metaphor but immediately has to reject it in order to make it "only" a metaphor, kind of supplement (Cembrzynska 2012, 62).

Tatlin's tower and Polish Palace are both parts of the same logic represented in literary texts. They are symbols of beyond-textual life, some real, ideological purposes but only if they reject their empirical qualities and become an immaterial sign of something which has not yet come into being. The abolition of the border between life and art - the main rule of the monumental propaganda - and creation of petrified utopia (as Jevgienij Dobrenko named this effect) has therefore eliminated the materiality of different form of art. The "body" of architecture — to remember the physiognomical background of Architecture Parlante—and its chaotic inside return in the literary texts as a specter.

According to Zygmunt Bauman, the authors of modern utopias do not distinguish social order from architectural (Cembrzynska 2012, 256). The concept of Lenin's plan and later Stalinist reanimation of its directives causes that monumental art cooperates with real, dynamic life. But it means that all distinctions have to be annihilated and the project of monumental utopia becomes rather a utopia of specters which haunt the immaterial buildings and spake with the voices of dreaming subjectivities.

\section{Works Cited}

Boris, Groys. The Total Art of Stalinism. Trans. Charles Rougle. Princeton: Princeton University Press, 1992.

Elizabeth, Klosty Beaujour, and Zamiatin. “Zamiatin 'We' and Modernist Architecture.” Russian Review 47.1 (1988): 49-60.

Jacques, Ranciere. The Politics of Aesthetics: The Distribution of the Sensible. Trans. Gabriel Rockhill. London: Continuum, 2004. 
James, Rann. "Maiakovskii and the Mobile Monument: Alternatives to Iconoclasm in Russian Culture." Slavic Review 71.4 (2012): 766-91.

Katerina, Clark. "The 'New Moscow' and the New 'Happiness:' Architecture as a Nodal Point in the Stalinist System of Value." Petrified Utopia. Happiness Soviet Style. Eds. Marina Balina and Evegny Dobrenko. London-New York-Delhi: Anthem Press, 2009. 189-201.

Krzysztof, Lipka. "Visionaries in the Service of Propaganda: Classical Revolutionary Architecture." Klasycyzm i klasycyzmy. Warsaw: PWN, 1994. 222-8.

Patrycja, Cembrzynska. Tower of Babel: Modern Project of Organizing World and its Deconstruction. Cracow: Universitas, 2012.

Roland, Barthes. "The Eiffel Tower." Selected Writings. Ed. Susan Sontag. 1989. <http://ahameri.com/cv/Courses/CU/Tourist\%20 Studio/Eiffel\%20Tower.pdf>.

Wojciech, Tomasik. Engineering of Souls. Literature of Socialist Realism in the Set of "Monumental Propaganda". Wroclove: FNP, 1999.

Zygmunt, Benedyktowicz. The Spectrum of the Center of the World: "Contexts: Polish Folk Art: Cultural Anthropology, Ethnography, Art”, Vol. 45. 1991. 